\title{
The first records of the occurrence of a North American invader Gammarus tigrinus Sexton, 1939 in the tributaries of the upper Vistula River
}

\author{
Iga Lewin ${ }^{1, *}$, Dariusz Halabowski ${ }^{1}$ and Zbigniew Rymarski ${ }^{2}$ \\ ${ }^{1}$ Department of Hydrobiology, Faculty of Biology and Environmental Protection, University of Silesia, Bankowa 9, 40-007 Katowice, \\ Poland \\ ${ }^{2}$ Institute of Electronics, Faculty of Automatic Control, Electronics and Computer Science, Silesian University of Technology, \\ Akademicka 16, 44-100 Gliwice, Poland
}

\begin{abstract}
The amphipod species Gammarus tigrinus, Sexton 1939 is native to the Atlantic coast of North America. The native range of its occurrence includes oligo- and mesohaline brackish waters with salinity of up to 14\%. Our survey was carried out in the tributaries of the upper Vistula River in Upper Silesia that is the most urbanised and industrialised region in Poland and constitutes one of the largest coal basins in the world. This survey uncovered the first occurrence of $G$. tigrinus with the maximum density of 1040 individuals $\mathrm{m}^{-2}$ in the tributaries of the upper Vistula River that have been polluted by coal mine water discharge. The occurrence of the invasive alien gastropod species, i.e. Potamopyrgus antipodarum (Gray, 1843) was also recorded in such salinised water. Our results showed that the anthropogenically salinised tributaries of the upper Vistula River constitute new habitats for euryhaline species and create new migration routes for alien and invasive species.
\end{abstract}

\begin{abstract}
Keywords: alien species / gammarid / river / salinisation
Résumé - Les premiers signalements de l'apparition d'un envahisseur nord-américain Gammarus tigrinus Sexton, 1939 dans les affluents de la Vistule supérieure. L'espèce d'amphipode Gammarus tigrinus, Sexton 1939 est originaire de la côte atlantique de l'Amérique du Nord. L'aire de répartition de sa présence naturelle comprend les eaux saumâtres oligo- et mésohalines d'une salinité allant jusqu'à 14\%o. Notre étude a été réalisée dans les affluents de la haute Vistule en Haute Silésie, la région la plus urbanisée et industrialisée de Pologne et qui constitue l'un des plus grands bassins houillers du monde. Ce relevé a mis en évidence la première occurrence de $G$. tigrinus avec une densité maximale de 1040 individus $\mathrm{m}^{-2}$ dans les affluents de la Vistule supérieure qui ont été pollués par les rejets d'eau des mines de charbon. La présence de l'espèce exotique envahissante de gastéropode, à savoir Potamopyrgus antipodarum (Gray, 1843) a également été enregistrée dans ces eaux salinisées. Nos résultats ont montré que les affluents anthropogéniquement salinisés de la haute Vistule constituent de nouveaux habitats pour les espèces euryhalines et créent de nouvelles voies de migration pour les espèces exotiques et envahissantes.
\end{abstract}

Mots-clés : espèces exotiques / gammaridé / rivière / salinisation

The amphipod species Gammarus tigrinus, Sexton (1939), which is typical of small and large estuaries or creek mouths, is native to the Atlantic coast of North America. The native range of its occurrence includes oligo- and mesohaline brackish waters with salinity of up to $14 \%$. Its range includes the estuary of the St. Lawrence River, the Chesapeake Bay, the estuary of the Potomac River and Florida (Bousfield, 1969). G.

\footnotetext{
*Corresponding author: iga.lewin@us.edu.pl
}

tigrinus colonised the Laurentian Great Lakes at density of 283 individuals $\mathrm{m}^{-2}$ during 2001-2004 (Grigorovich et al., 2005). In Europe, it was found in the brackish waters of the Salwarpe River (the Droitwich district, UK) for the first time in 1931 (Sexton, 1939) (Fig. 1). G. tigrinus was deliberately introduced into German rivers, which had been heavily polluted by the potash mining industry, i.e. the Weser and the Werra in 1957 from England to compensate for a decrease in the native amphipod species (Bäthe and Coring, 2011; Braukmann and Böhme, 2011). This North American species then began to 


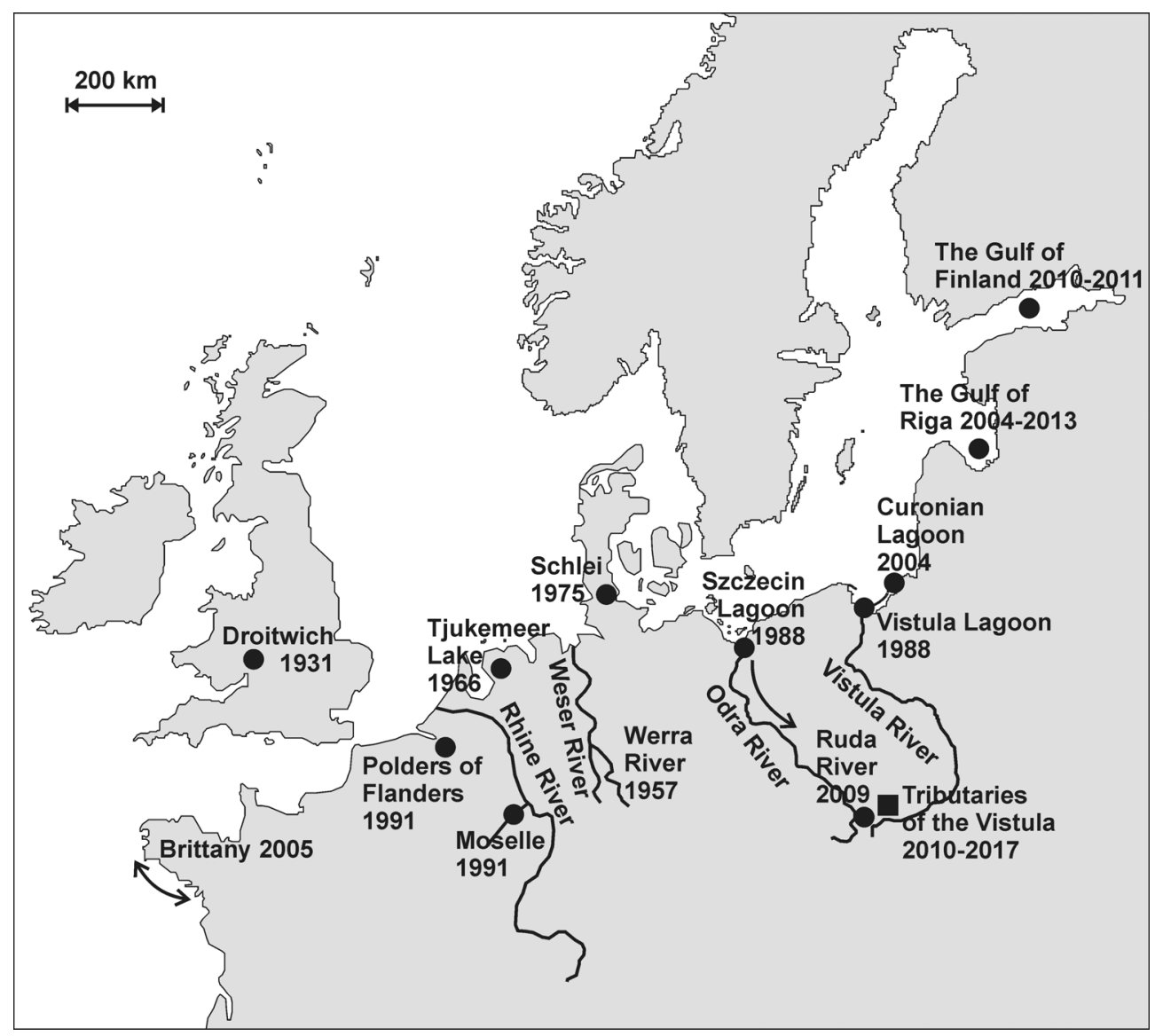

Fig. 1. The distribution and possible migration routes of Gammarus tigrinus, Sexton 1939 in Europe (Author: Z. Rymarski).

occur in the inland waters of continental Europe. G. tigrinus was recorded in the Netherlands at a density up to 24000 individuals $\mathrm{m}^{-2}$ in 1960 (Chambers, 1977). In 1991, this amphipod was first recorded in the Moselle River, an oligohaline tributary of the Rhine River (north-eastern France) from where it dispersed to the other catchments of the rivers (the Saône, the Rhône, the Loire Rivers) via canals. It was first reported along the southern cost of Brittany in 2005 (Piscart et al., 2005; 2008). G. tigrinus was first recorded in the Schlei estuary in the Baltic Sea (Germany) in 1975 (Pienimäki et al., 2004). G. tigrinus continued its spread to the Szczecin Lagoon (Poland) by 1990 (Gruszka, 1999) and it had reached the Vistula Lagoon by 1998 (Jazdzewski et al., 2004). By 2007, this amphipod species was recorded in the lower and middle courses of the Odra River (Grabowski et al., 2007) and was continuing to spread upstream. Recently, it has been found in the tributaries and catchment of the upper Odra River (Spyra et al., 2015; Sowa et al., 2018). Simultaneously, G. tigrinus has successfully continued its spread within the Baltic Sea (Pienimäki et al., 2004; Daunys and Zettler, 2006; Kotta et al., 2013; Strode et al., 2013) (Fig. 1).

Our survey was carried out in the tributaries of the upper Vistula River from 2010 to 2017 (Upper Silesia and adjacent areas, Poland). The Vistula River has a total length of $1047 \mathrm{~km}$ and a catchment area of $194424 \mathrm{~km}^{2}$ (the longest river in Poland). Upper Silesia is the most urbanised and industrialised region in Poland and constitutes one of the largest coal basins in the world. Three tributaries of the upper Vistula River, i.e. the Potok Gromiecki River, the Gostynia River, the Mleczna River as well as the inflow into the Mleczna River from a coal mine dewatering system were investigated. The waters of these tributaries are characterised by high levels of chlorides, sulphates, biogenic elements or conductivity, which is a consequence of the discharge of mine waters from the coal mine dewatering system into the rivers. Samples of the macroinvertebrates were collected according to quantitative methods and the physical and chemical parameters of the water were also analysed (Tab. 1). This survey uncovered the first occurrence of G. tigrinus in the tributaries of the upper Vistula River (Fig. 2).

Amphipods were identified to the species level according to Eggers and Martens (2001). The maximum density of $G$. tigrinus was 1040 individuals $\mathrm{m}^{-2}$ in the tributaries of the upper Vistula River. The occurrence of the invasive alien gastropod species, i.e. Potamopyrgus antipodarum (Gray, 1843) and alien species Physa acuta Draparnaud, 1805 were also recorded in such salinised water. The density of $G$. tigrinus decreased to only a few specimens in the Potok Gromiecki River when the conductivity of the water increased to $40900\left(\mu \mathrm{S} \mathrm{cm}^{-1}\right)$ as a consequence of coal mine water discharge into the river. Our survey showed the first occurrence of $G$. tigrinus in rivers with a relatively high conductivity (salinity) (Tab. 2).

This euryhaline gammarid species tolerates salinity of up to 25 PSU (Pienimäki et al., 2004). According to the surveys of Jazdzewski et al. (2004) and Grabowski et al. (2009), G. 
Table 1. Density (individuals $\mathrm{m}^{-2}$ ) of Gammarus tigrinus and Potamopyrgus antipodarum in relation to the physical and chemical parameters of the water (ranges) in the tributaries of the upper Vistula River.

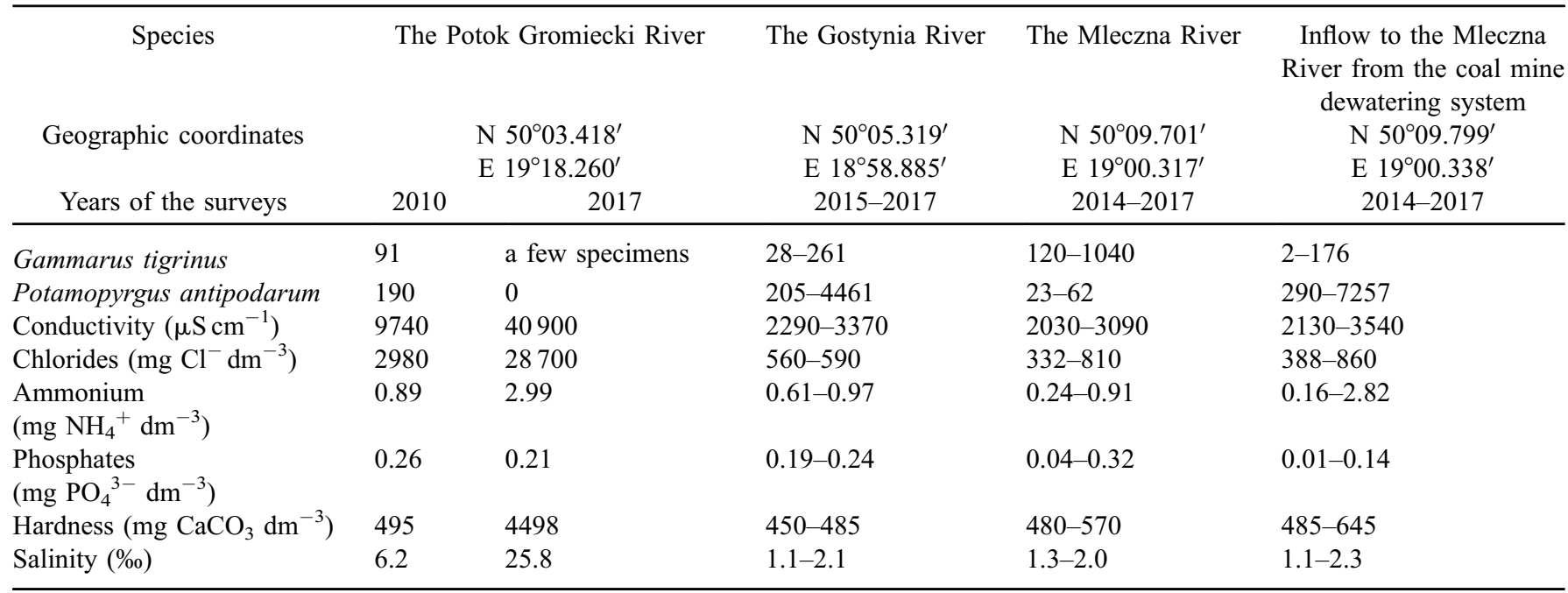

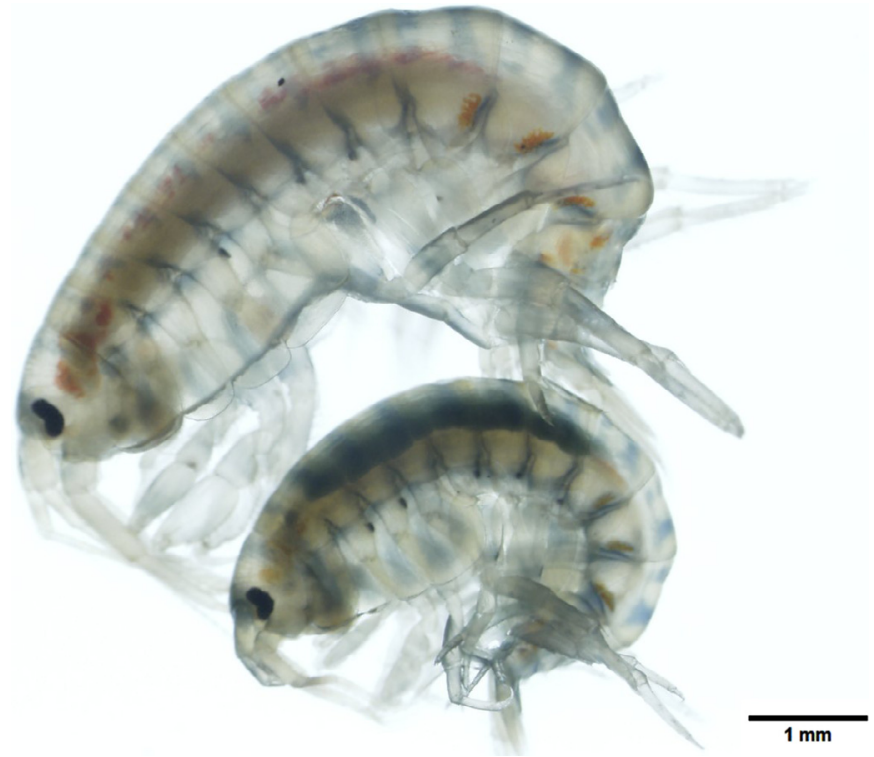

Fig. 2. Male and female Gammarus tigrinus Sexton, 1939 in a tributary of the upper Vistula River (The Mleczna River) (Author: D. Halabowski).

tigrinus thrives especially well in oligohaline waters of conductivity ranged from 1000 to $8000 \mu \mathrm{S} \mathrm{cm}^{-1}(0.5-$ 4.0 PSU) and is a very successful invader in the Dead Vistula and in the Vistula Lagoon.

Two different possible patterns of G. tigrinus migration to the tributaries of the upper Vistula River can be considered. The first one is the dispersal of G. tigrinus from the upper course of the Odra River to the tributaries of the upper Vistula River by the local inland canal-river systems. G. tigrinus spreads within the riverine habitats in the Odra River that are well connected to other European waterways (SzlauerŁukaszewska et al., 2018). G. tigrinus is often found in ecosystems disturbed by anthropogenic pollution including salinisation. Such ecosystems are typical of Upper Silesia. It was also shown that specimens of amphipods are able to attach to invertebrates (molluscs, rotifers or infusorians) that can be considered as possible vectors of their accidental introduction (Berezina, 2007). The upstream migration of $G$. tigrinus from the Vistula Lagoon may be considered as the second possible path of the dispersion. However, the result of Grabowski et al. (2007) showed that the distribution of $G$. tigrinus was limited exclusively to the brackish parts of the Vistula Lagoon or the Vistula River mouth and that the gammarid had not dispersed upstream. Therefore, the possible migration route of $G$. tigrinus into the tributaries of the upper Vistula River is not known and this requires further research.

According to Grabowski et al. (2007), G. tigrinus had replaced the native invertebrates, including other gammarid species in most of the colonised habitats. The high degree of invasive potential and its capacity for further expansion is related to its higher fecundity, smaller size at breeding and an earlier start of the breeding season, significant predation pressure as well as its ability to tolerate a broader range of environmental conditions compared to the native gammarids (Jänes et al., 2015). Grabowski et al. (2009) revealed that the small, natural tributaries of large rivers (the Odra, the Vistula Rivers) may function as refugia for the native amphipod fauna. In contrast, our results showed that the anthropogenically salinised tributaries (coal mine water discharge) of a large river (the upper Vistula River) constitute new habitats for euryhaline species and create new migration routes for alien and invasive species, e.g. for G. tigrinus and P. antipodarum.

Acknowledgements. The authors are deeply indebted to the Editor-in-Chief and to the anonymous reviewers for their valuable suggestions and comments which significantly improved the quality of this manuscript.

The authors are also grateful to Ms. Michele L. Simmons, B.A., University of Silesia, Faculty of Biology and Environmental Protection, Katowice, Poland, for improving the English style. 
Table 2. Examples of the occurrence of Gammarus tigrinus in relation to the conductivity, concentration of chlorides in the water and salinity in inland and coastal habitats.

\begin{tabular}{|c|c|c|c|c|c|}
\hline $\begin{array}{l}\text { Conductivity } \\
\left(\mu \mathrm{S} \mathrm{cm}^{-1}\right)\end{array}$ & $\begin{array}{c}\text { Chlorides } \\
\left(\mathrm{mg} \mathrm{Cl}^{-} \mathrm{dm}^{-3}\right)\end{array}$ & $\begin{array}{l}\text { Salinity } \\
\text { (PSU) }\end{array}$ & $\begin{array}{c}\text { Density } \\
{\text { (individuals } \mathrm{m}^{-2} \text { ) }}\end{array}$ & Area of occurrence, country & References \\
\hline 15500 & & & & Watch Lane Flash (lake) England & Savage (1982) \\
\hline 3422 & & & & The Meurthe River, France & Piscart et al. (2005) \\
\hline \multirow[t]{2}{*}{2800} & & & & Bivet, Brittany, France & Piscart et al. (2008) \\
\hline & 5860 & & & $\begin{array}{l}\text { Brackish polder in Flanders } \\
\text { (Belgium) }\end{array}$ & Boets et al. (2011) \\
\hline 8500 & 2500 & 4.6 & 3500 & The Werra River (Germany) & $\begin{array}{l}\text { Braukmann and Böhme (2011); } \\
\text { Bäthe and Coring (2011); } \\
\text { Arle and Wagner (2013) }\end{array}$ \\
\hline \multirow[t]{7}{*}{2870} & & & & The Odra River (Poland) & Rachalewski et al. (2013) \\
\hline & & $1.4-3.5$ & 1520 & The Vistula Lagoon & $\begin{array}{l}\text { Jazdzewski et al. (2004); } \\
\text { Grabowski et al. (2006); } \\
\text { Dobrzycka-Krahel et al. (2013) }\end{array}$ \\
\hline & & $0.2-4.9$ & 74 & The Vistula Delta & Dobrzycka-Krahel et al. (2013) \\
\hline & & & 6399 & Puck Bay & Janas and Kedzierska (2014) \\
\hline & & $0-10.0$ & 10767 & The Gulf of Finland & Kotta et al. (2013) \\
\hline & & & $1-70$ & $\begin{array}{l}\text { The Latvian waters of the } \\
\text { Gulf of Riga }\end{array}$ & Strode et al. (2013) \\
\hline & & $4.5-6.0$ & 110-508; maximum 4700 & The Gulf of Riga & Reisalu et al. (2016) \\
\hline
\end{tabular}

\section{References}

Arle J, Wagner F. 2013. Effects of anthropogenic salinization on the ecological status of macroinvertebrate assemblages in the Werra River (Thuringia, Germany). Hydrobiologia 701: 129-148. DOI: 10.1007/s10750-012-1265-z.

Bäthe J, Coring E. 2011. Biological effects of anthropogenic salt-load on the aquatic fauna: a synthesis of 17 years of biological survey on the rivers Werra and Weser. Limnologica 41: 125-133. DOI: 10.1016/j.limno.2010.07.005.

Berezina NA. 2007. Invasions of alien amphipods (Amphipoda: Gammaridea) in aquatic ecosystems of North-Western Russia: pathways and consequences. Hydrobiologia 590: 15-29. DOI:10.1007/s10750-007-0753-z.

Boets P, Lock K, Goethals PLM. 2011. Shifts in the gammarid (Amphipoda) fauna of brackish polder waters in Flanders (Belgium). J Crustacean Biol 31: 270-277. DOI:10.1651/103357.1.

Bousfield EL. 1969. New records of Gammarus (Crustacea: Amphipoda) from the middle Atlantic Region. Chesapeake Sci 10: 1-17.

Braukmann U, Böhme D. 2011. Salt pollution of the middle and lower sections of the river Werra (Germany) and its impact on benthic macroinvertebrates. Limnologica 41: 113-124. DOI:10.1016/j. limno.2010.09.003.

Chambers MR. 1977. The population ecology of Gammarus tigrinus (Sexton) in the reed beds of the Tjeukemeer. Hydrobiologia 53: $155-164$.

Daunys D, Zettler ML. 2006. Invasion of the North American amphipod (Gammarus tigrinus Sexton, 1939) into the Curonian Lagoon, south-eastern Baltic Sea. Acta Zool Litu 16: $20-26$.

Dobrzycka-Krahel A, Tarała A, Chabowska A. 2013. Expansion of alien gammarids in the Vistula Lagoon and the Vistula Delta (Poland). Environ Monit Assess 185: 5165-5175. DOI:10.1007/ s10661-012-2933-1.
Eggers TO, Martens A. 2001. A key to the freshwater Amphipoda (Crustacea) of Germany. Lauterbornia 42: 1-70.

Grabowski M, Konopacka A, Jazdzewski K, Janowska E. 2006. Invasions of alien gammarid species and retreat of natives in the Vistula Lagoon (Baltic Sea, Poland). Helgol Mar Res 60: 90-97. DOI: 10.1007/s10152-006-0025-8.

Grabowski M, Jazdz ewski K, Konopacka A. 2007. Alien crustacea in Polish waters - Amphipoda. Aquat Invasions 2: 25-38. http://dx. doi.org/10.3391/ai.2007.2.1.3.

Grabowski M, Bacela K, Konopacka A, Jazdzewski K. 2009. Salinity-related distribution of alien amphipods in rivers provides refugia for native species. Biol Invasions 11: 2107-2117. DOI: 10.1007/s10530-009-9502-8.

Grigorovich IA, Kang M, Ciborowski JJH. 2005. Colonization of the Laurentian Great Lakes by the amphipod Gammarus tigrinus, a native of the North American Atlantic Coast. $J$ Great Lakes Res 31: 333-342, https://doi.org/10.1016/ S0380-1330(05)70264-1.

Gruszka P. 1999. The river Odra estuary as a gateway for alien species immigration to the Baltic Sea basin. Acta Hydrochim Hydrobiol 27: 374-382.

Janas U, Kedzierska H. 2014. Benthic non-indigenous species among indigenous species and their habitat preferences in Puck Bay (Southern Baltic Sea). Oceanologia 56: 603-628. DOI:10.5697/ oc.56-3.603.

Jänes H, Kotta J, Herkül K. 2015. High fecundity and predation pressure of the invasive Gammarus tigrinus cause decline of indigenous gammarids. Estuar Coast Shelf Sci 165: 185-189, http://dx.doi.org/10.1016/j.ecss.2015.05.014.

Jazdzewski K, Konopacka A, Grabowski M. 2004. Recent drastic changes in the gammarid fauna (Crustacea, Amphipoda) of the Vistula River deltaic system in Poland caused by alien invaders. Divers Distrib 10: 81-87.

Kotta J, Pärnoja M, Katajisto T, Lehtiniemi M, Malavin SA, Reisalu $\mathrm{G}$, Panov VE. 2013. Is a rapid expansion of the invasive amphipod Gammarus tigrinus Sexton, 1939 associated with its niche 
selection: a case study in the Gulf of Finland, the Baltic Sea. Aquat Invasions 8: 319-332.

Pienimäki M, Helavuori M, Leppäkoski E. 2004. First findings of the North American amphipod Gammarus tigrinus Sexton, 1939 along the Finnish coast. Memo Soc Pro Fauna Flora Fenn 80: 17-19.

Piscart C, Moreteau J-C, Beisel J-N. 2005. Biodiversity and structure of macroinvertebrate communities along a small permanent salinity gradient (Meurthe River, France). Hydrobiologia 551: 227-236. DOI:10.1007/s10750-005-4463-0.

Piscart C, Maazouzi C, Marmonier P. 2008. Range expansion of the North American alien amphipod Gammarus tigrinus Sexton, 1939 (Crustacea: Gammaridae) in Brittany, France. Aquat Invasions 3: 449-453.

Rachalewski M, Konopacka A, Grabowski M, Bącela-Spychalska K. 2013. Echinogammarus trichiatus (Martynov, 1932) - a new Ponto-Caspian amphipod invader in Poland with remarks on other alien amphipods from the Oder River. Crustaceana 86: 1224-1233. DOI:10.1163/15685403-00003228.

Reisalu G, Kotta J, Herkül K, Kotta I. 2016. The invasive amphipod Gammarus tigrinus Sexton, 1939 displaces native gammarid amphipods from sheltered macrophyte habitats of the Gulf of Riga. Aquat Invasions 11: 45-54.
Savage AA. 1982. The survival and growth of Gammarus tigrinus Sexton (Crustacea: Amphipoda) in relation to salinity and temperature. Hydrobiologia 94: 201-212.

Sexton EW. 1939. On a new species of Gammarus (G. tigrinus) from Droitwich district. J Mar Biol Assoc UK 23: 543-554.

Sowa A, Krodkiewska M, Halabowski D. 2018. Macroinvertebrate communities on various microhabitats of a saline coal mine settling pond. Oceanol Hydrobiol Stud 47: 50-59 https://doi.org/10.1515/ ohs-2018-0006.

Spyra A, Kubicka J, Strzelec M. 2015. The influence of the disturbed continuity of the river and the invasive species - Potamopyrgus antipodarum (Gray, 1843), Gammarus tigrinus (Sexton, 1939) on benthos fauna: a case study on urban area in the River Ruda (Poland). Environ Manag 56: 233-244. DOI: 10.1007/ s00267-015-0483-3.

Strode E, Berezina NA, Kalnins M, Balode M. 2013. New records of the amphipod Gammarus tigrinus Sexton, 1939 and Pontogammarus robustoides G.O. Sars, 1894 in Latvian waters of the Baltic Sea. BioInv Rec 2: 63-68.

Szlauer-Łukaszewska A, Hupało K, Grabowski M. 2018. Spatial distribution of alien gammarids in a large European river (Oder River, Poland). Knowl Manag Aquat Ecosyst (in press).

Cite this article as: Lewin I, Halabowski D, Rymarski Z. 2018. The first records of the occurrence of a North American invader Gammarus tigrinus Sexton, 1939 in the tributaries of the upper Vistula River. Knowl. Manag. Aquat. Ecosyst., 419, 31. 